\title{
TTR
}

Traduction, terminologie, re?daction

\section{Towards a Model of Literary. Translation in Canada}

\section{E. D. Blodgett}

Volume 4, numéro 2, 2e semestre 1991

Traduire la théorie

URI : https://id.erudit.org/iderudit/037098ar

DOI : https://doi.org/10.7202/037098ar

Aller au sommaire du numéro

Éditeur(s)

Association canadienne de traductologie

ISSN

0835-8443 (imprimé)

1708-2188 (numérique)

Découvrir la revue

Citer cet article

Blodgett, E. D. (1991). Towards a Model of Literary. Translation in Canada. TTR, 4(2), 189-206. https://doi.org/10.7202/037098ar d'utilisation que vous pouvez consulter en ligne.

https://apropos.erudit.org/fr/usagers/politique-dutilisation/ 


\title{
Towards a Model of Literary Translation in Canada ${ }^{1}$
}

\author{
E. D. Blodgett
}

In memoriam Larry Shouldice (1945-1991)

This paper proposes a model for the practice of literary translation in Canada. It is based, from the most part, upon a reading of the Dialogue sur la traduction, conducted by Anne Hébert and F.R. Scott, which may be perceived as an exemplary text for the model proposed. My discussion proceeds from certain assumptions, most of which are set forth in what has been called the "new paradigm" for literary translation studies (Hermans, pp. 10-15). I wish, therefore, to begin by briefly setting forth the position of the old paradigm and contrasting it with the new one. Inasmuch as the new paradigm possesses certain limitations when used for the analysis of Canadian literary practice, I shall also indicate the point at which I differ with it.

The old paradigm begins with a fundamental assumption which privileges the source-text. Hence, it easily lends itself to such proverbial statements as traduttore, traditore, which Roman Jakobson

1. I should like to express my warm gratitude to Gideon Toury and Anthony Purdy for their suggestions and advice at an earlier stage in the preparation of this article. A briefer version of this paper was presented at the Association for Canadian Studies in the United States in November 1989. 
renders as a pair of questions: "translator of what messages? betrayer of what values?" (Jakobson, p. 238). Because the translated text is never much better than a pis-aller it never accedes to the same ontological status as the original text. As a consequence, Jakobson's assertion that "poetry, by definition, is untranslatable" (Jakobson, p. 238) sums up the position of many. Translations, furthermore, are often held to be of "minor significance" and put into the same category as "parody, pastiche, stage and screen adaptations, children's literature [and] popular literature" (Hermans, p. 8). Thus, translations do no more than reproduce (Levy, pp. 65-66).

All these assumptions depend upon almost automatic and certainly culturally prompted privileging acts the define the source-text as an origin. The notion is at once romantic and essentialist (Hermans, p. 7). The specific weight of George Steiner's lengthy study of translation, for example, is designed to argue that what he calls the "hermeneutic motion" of translating goes through a series of operations that in the end triumphantly serves the text from which it departs. "Translation," he writes, "recompenses in that it can provide the original with a persistence and geographical-cultural range of survival which it would otherwise lack" (Steiner, pp. 395-96). "Reciprocal enhancement" (Steiner, p. 395) would seem to be the highest achievement of the "good" translation, but, nevertheless, the translation is only good insofar as it serves the continued life of the original.

The new paradigm proceeds from an assumption which, in effect, privileges the target-text. Because the notion of origin may be considered secondary (Paz, p. 1080), it is more prudent to examine the literary translation within a whole target system. Inasmuch as the translation is a paraliterary text at certain moments of its publishing history, it is often difficult to distinguish it from the non-translated text (Even-Zohar 1978, p. 124). Such an assertion implies that the translated text, then, is subject to the same kind of instability to which a given literary corpus is subject (Lefevere). If, however, the weight of analysis falls upon the relation of the translated text to the target-system, one is forced to reconsider how a translation is to be assessed. Hence, the question of equivalence between source and target-text is a function of norms that depend upon whether the translator chooses adequacy with 
respect to the source-text or acceptability in the polysystem of the target-language (Toury 1980, p. 69).

The fundamental oppositions between the two sets of assumptions I have just sketched turn, it seems to me, upon the question of ideology. The traditional view assumes the ontological priority of origin. As a consequence, a source-text is a problem that requires a solution (Toury 1980 , p. 40). The central point of such scholars as Itamar Even-Zohar, Gideon Toury, and Jose Lambert is that translation, like any other literary activity, is properly to be seen as both part of a plurality of interacting systems, which are historically and functionally determined. The value of their project - the project of the new paradigm - is that it assumes the possibility of proceeding in an approximate scientific manner. Furthermore, by removing translation studies from the limited zone of problem-solving, it places the translated text within the complex network of systems in which its actual existence occurs.

The significance of the new paradigm for students of the Canadian literatures cannot be overlooked. The translation becomes the field that both relates the literatures of Canada and problematizes their relationship. It also makes it impossible to speak, as most critics do, of these literatures, as if there were only one (cf. Blodgett, pp. 13-38). Another consequence is that it permits literary activity to be defined with respect to the systems within which it operates and with which it interferes. As Clement Moisan argues, there are four levels of systemic activity (Moisan, pp. 124-25):

1. The fields of literary and non-literary production.

2. Literature as the product of distribution/consumption within an economic structure.

3. The fields of legitimation and canonization.

4. The teaching of literature, including criticism and prizes.

While it is possible that levels three and four overlap, such a framework is designed to place the text (whether translated or not) within those contexts and co-texts of significance that emphasize the kinds of value one wishes to assign it. Thus the static privileging of origin of any kind is not permitted. As a result, the translated text may 
claim a value not normally granted to it, suggesting that the target-text is a problem (as well as a solution) for the "target"-literature. ${ }^{2}$

Let us now consider the Dialogue sur la traduction. The purpose of such analysis is not only to propose a reading of it within the limits of polysystem theory but also to argue that it may serve as the basis for a model of literary translation in Canada. The significance of the Dialogue is that it contains not one, but many texts. Taken together, these texts suggest that Anne Hébert's "Le Tombeau des rois" is not simply an origin or source-text, but rather a pretext for a discussion of a number of problems. The translator is F.R. Scott, a Canadian poet as distinguished as Hébert, and who was also an academic, legal expert, and political figure. The fact that he decided to translate Hébert - or any other French-Canadian poet - would assure that the translated text would achieve a certain recognition in the English-Canadian polysystem. Inasmuch as he has been described by John Glassco as "Canada's first artistic translator of poetry" (Stratford, p. 102), and whose method served as a "standard followed by many younger translators" (Stratford, p. 103), attention to his practice reveals a great deal about the strategies of the translation of poetry in English Canada.

As a product of the literary institution in Canada, Dialogue is of special significance, however, for, as the title implies, it was published in Québec. Thus, the target audience appears to be francophone; but while the preface is given in English, then translated, the dialogue is given in Hébert's French and Scott's English, as well as their letters to each other. One might justifiably ask, then, what kind of audience is intended, inasmuch as Hébert for a francophone audience cannot constitute a problem in translation. As I shall indicate, such a question leads to two others, namely, what kind of text the translator produces and upon what text it is based. The audience sought is clearly one whose concern is the problematics of translation, rather than Hébert

2. I find it necessary to use quotation marks inasmuch as literary studies that make use of both polysystem theory and theories of the literary institution make the word "target" an almost anomalous term. This is especially true when a translation achieves canonic stature, e.g., The King James Bible. 
in English. Thus, the text is designed to illustrate how a translation is process, thus privileging the target-system. Not only are three versions of Hébert's poem given in diachronic elaboration, but also their lack of closure is a matter of emphasis (Hébert and Scott, p. 94). Because of the stress on process, the significance of Hébert's poem becomes continuously more ambiguous as source- and pretext. Indeed, those texts that are used to present the translations, which are, in effect, paratexts of legitimation, are as important as Hébert's and Scott's texts. These texts by Northrop Frye and Jeanne Lapointe are intent upon one point, namely, the problem of meaning. While they may not intend it, such a discussion cannot help but question the ontological status of Hébert's poem, even as they appear to support it.

In his preface Northrop Frye addresses immediately the problem of meaning and its kinds: first, meaning is dependent upon context, and second, its verbal context is either that of literature or that of "ordinary explicit or intentional discourse" (Hébert and Scott, p. 12). Needless to say, "literature" for Frye is not understood as possessing an institutional significance, and he moves directly to poetry and argues that our initial operation in reading a poem is "to grasp its explicit meaning, or the prose sense of what it says" (Hébert and Scott, p. 12). He then remarks that "[w]e often call this the 'literal' meaning, but actually it is a translation of the poem into a different verbal context" (Hébert and Scott, p. 12). All interpretation, then, is an act of translation that makes the translated text accessible to constraints understood by the reader. When the reader is a translator in a strict sense, he is also a writer producing a text subject to the constraints of the target language, whether it is literary or non-literary, prose or poetry, and subject to the norms of genre models, which is part of Toury's argument. Frye goes on to assert that Scott distinguished between the poem's surface and "real" meaning, and by choosing the latter, chose "a literal rendering of the real and not the superficial meaning" (Hébert and Scott, p. 13). Thus Scott's dialogue with Hébert concerns "the proper context of meaning" (Hébert and Scott,p. 13), and one of its consequences is that Hébert herself "would never have discovered so much about her own meaning" (Hébert and Scott, p. 13).

While such a conclusion may seem to confirm Steiner's notion of reciprocal enhancement - and indeed one reading of Dialogue 
would seem to be the promotion of dialogue between Canada's two major linguistic communities at a time of political crisis (the book was published in 1970) - I would argue that both Frye's preface and the book's presentation by Jeanne Lapointe choose to dwell upon all the poems within an apparently more ideologically neutral context of language and meaning. Lapointe is more metaphorical than Frye, preferring to see two poets at work, and to describe Scott's role as poet/translator as one who assists at a rebirth of a poem "de l'océan du langage" (Hébert and Scott, p. 33). Such an act is symmetrically related to Hébert's own, who is cited as perceiving the poem as "traduit d'abord du fond du coeur'" (Hébert and Scott, p. 33).

In her letter to Scott, Hébert remarks upon the same issue that Frye raises: a certain kind of literalness with respect to what is most apparent turns poetry into prose. What is never sought are poetic equivalences (Hébert and Scott, pp. 48-49); and as their dialogue makes clear, these can be derived only from the target-system, as distinct from the source-system. The point of such an exchange is to distinguish various kinds of literal renderings, one which tends toward prose and another that corrsponds to the source-text as poetry. Hence, Scott's reply: "The translation then becomes another making, demanding the same kind of ability and vision as the author possessed, with the same careful selection of words, phrases and sounds. The difference is that the translator is given an external criterion of the appropriateness of his writing, in the poem to be translated" (Hebert and Scott, p. 56). The response is, in appearance at least, paradoxical, for "same" refers to the differences that distinguish the two languages. What text, we are prompted to ask, is the translator "making," to use Scott's word?

To answer that question, let me refer to one of Even-Zohar's comments on the implications of polysystem theory: "translated literature may possess modelling principles of its own, which to a certain extent could be exclusive to it" (Even-Zohar 1978, p. 118). The problem for the researcher is to determine what principles are at work, for they are not always materially manifest. As he himself has remarked, polysystem theory is not a method of classification that would identify "'literature' with its (textual) products." It is, rather, a "correlation between repertoire and system, or between production, products and consumption" (Even-Zohar 1990, p. 5). One way of 
analysing these relationships is through studies of the literary institution. Another is to inquire in what way translated literature manifests "modelling principles of its own." In the instance of Scott, all his revisons tend toward "the most literal translation" (Hébert and Scott, p. 81), which would suggest a contradiction in Hébert's praise for his desire to find poetic equivalents. It would seem that adequacy and acceptability coincide in Scott's version (Toury, 1978, 88-89). Since "adequacy" is only used with respect to the source-text, one wants to know what the source-text is. The statement, furthermore, has particular relevance in light of Even-Zohar's comment, if I paraphrase him correctly, that literature is not manifest in texts only. I want to suggest, then, that part of the discussion of meaning in the Dialogue, which all of the texts address in various ways, turns not only upon the apparent source-text ("Le Tombeau des rois"), but also upon another source-text not immediately apparent.

Scott's final statement on the process is remarkable for its sensitivity to the problem of closure in making a poem. This is because "the original poern is itself a translation into a chosen language of that inner stirring of emotion and thought which started the poem on the act of creation" (Hébert and Scott, p. 94). Because no feeling or thought can be rendered with precision, there is always a disparity between adequacy and acceptability, if I may use these terms in a slightly different context, even in an "original" poem. As he remarks elsewhere, "of an original poem it has been said that it is never finished, only abandoned" (Scott i). The analogy between making a poem and a translation is instructive, for it implies a source-text that is not, and never will be, materially evident.

What Scott invokes here, and Hébert elsewhere, is akin to Kristeva's idea of the pheno-text and geno-text, in which the latter would appear to correspond to a source-text. For as much as Scott must seek meaning, so Hébert, as she observes of herself as a poet, "est également engagé dans cette aventure lucide et forte qui consiste à saisir de plein jour, sans faiblesse, cette poésie souvent reçue et donnée dans l'éclatement de l'être le plus obscur et le plus innocent" (50). In Kristeva's more general terms, the pheno-text is the text as it appears. The geno-text is the initial phase of the signifying process which issues in the pheno-text. It is characterized by 
les transports d'énérgie pulsionnelle repérables dans le dispositif phonématique [...] et mélodique [...], aussi bien que dans la disposition des champs sémantiques et catégoriels tels qu'ils apparaissent dans les particularités syntaxiques et logiques ou dans l'économie de la mimesis (fantasme, suspension de la dénotation, récit, etc.). (Kristeva, p. 83)

As we have seen, what is evident in the dialogue between Scott and Hébert is that for them, as well as for Frye and Lapointe, the level of semantic production is their first concern. The source-text must be a geno-text, but the question I wish to examine is whether it is the same geno-text or does each pheno-text that Hébert and Scott produce depend upon different geno-texts?

Because of the constraints imposed by both the source-language and the target-language, I want to argue that the geno-texts, while homologous, are not the same. This means that the relation of the two pheno-texts is only an approximation of the relation of the two genotexts. If one were to schematisize the continuous relationship between all four texts, it would appear as follows:

geno-text 1

pheno-text 2

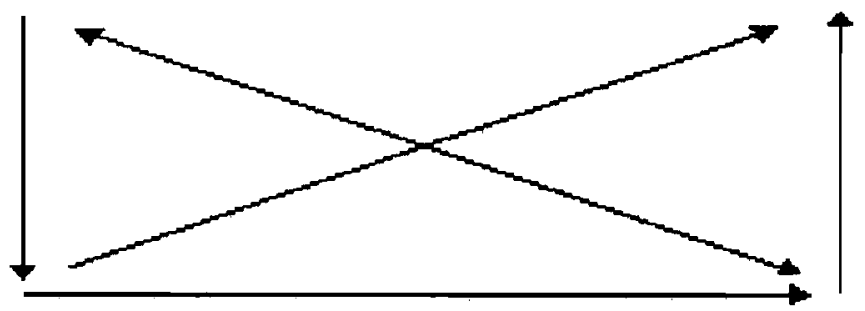

pheno-text 1

geno-text 2

3. Theorists of translation are fundamentally enamoured of communication models, and I have proposed this one not for its own sake, but for whatever light it may shed on the relation of the Canadian literatures through translated texts. For a useful summary of a number of models, see Kelly, ch. 2 . 
The desired norm, if there is a norm for translation procedures, would follow the continuous lines from geno-text 1 to phenotext 1 , that serves as a model, thence to pheno-text 2 on the broken line. This movement would appear to produce a "transparent" reproduction of the source-text. It is with respect to such an assumption that, for example, Marchand argues that Scott fails to recuperate Hébert's poem. While he accepts that the central preoccupation of the dialogue addresses the semantic level of the poem, he does not accept Scott's argument that, in effect, a poem and its translation share the same ontological position. As he states,

Le traducteur ne peut éviter le modèle qu'il a sous ses yeux, en l'occurrence le texte à traduire. C'est pourquoi l'idée d'un à priori à l'acte poétique est apparue chez Frank Scott: si le traducteur doit réviser son travail afin de le rapprocher de son modèle, pourquoi n'en serait-il pas ainsi du poète qui révise son travail? (Marchand, p. 158)

It is precisely the "a priori d'un acte poetique," which I would designate geno-text 2. Scott, as Marchand observes, avoids the visible model of Hébert's poem, pheno-text 1, for the sake of another, and such a decision would explain the semantic inadequacy of his versions. An even more unsurmountable problem in poetic translation than semantic equivalence is that of phonetic similarity. As Marchand observes, Hébert herself found Scott wanting in this respect. As a consequence, Scott changes the narrator's attitude in his versions. Hébert's poem is characterized by a variety of phonetic oppostions and clashes that Scott softens: "le poème anglais tend vers l'harmonie et le raffinement alors que l'œuvre originale tend à nier constamment, par des voies détournées, tout ce qu'elle peut contenir de sacré" (Marchand, p. 160). The conclusion of the whole argument, which follows along the lines of what we have referred to as the old paradigm, is perhaps forseeable: it is to return the reader to the source-text, which should serve as the improperly construed geno-text of Scott's poem. But, as Kristeva argues, a geno-text is not a model, but rather an "articulation incertaine 
et indéterminée." ${ }^{14}$ This would suggest that in the process of translation, a signifying process between two languages, thus duplicating Kristeva's concept, the translator is stimulated by the source-text (pheno-text 1) to pay attention to the activity of a geno-text that will assist in the production of a target-text. In Scott's case, his geno-text will perforce differ from Hébert's. The schema is designed to evoke that difference.

Returning to the schema and bearing mind Scott's commentary, it would appear that his practice was to follow the continuous line on the outside, passing through geno-text 2 . This is especially apparent in the analogy Scott draws between the activity of the poet and the translator. Just as "the original poem is itself a translation of that inner stirring of emotion and thought which started the poet on the act of creation," so too is the translated version. Furthermore, in his discussions with Hébert, he seemed, at least, to move along the broken line that connects the two geno-texts, forcing her, as I have indicated, to reexamine what the semantic dimension of the source text might be, just as Scott did for the target-text. The significance, then, of the schema and the relationships that it sets forth is to indicate that the translation process, at least as suggested by Dialogue, is such that transfer is mediated not by the pheno-text entirely, but also by the genotext that produces the target-text. Disposed toward the target-text, it shapes the signifying process, but in the target-language, providing the means that will issue in a correspondingly different syntax, melody, semantic order. This, I take it, is the the central point concerning meaning that all the texts address, and the function of the dialogue was to discover through mutual effort those sources from which both sourceand target-text emerge at the generative level. One might say, then, that geno-text 2 regulates the constraints that are manifest in the target-text, and it (geno-text 2), in turn is regulated by the source-text. Hence, it differs manifestly from geno-text 1 , which appears to have no particular constraints. As a consequence, it interposes itself against the apparent source-text - the pheno-source-text — and becomes a geno-source-text.

4. Although this part of Kristeva's argument bears upon her notion of chora as developed from Plato, chora is clearly in analogy with the the idea of geno-text. 
It is at precisely this mediating point that translation has a certain significance in the study of the Canadian literatures, when carried out within the framework of polysystem theory. Because Canada is officially bilingual, translation is more than a mere craft; it is, and has been for generations, a political necessity. ${ }^{5}$ Canada is not unique in this respect, but it is among those countries in which polysystem theory is capable of thriving, precisely because bilingual countries, by definition, are situations where the assymetries that polysystem theory identifies (primary vs. secondary, centre vs. margin, etc.) may be readily noticed and acknowledged. The problem for scholars of polysystem theory is the conditions under which principles of relationship act in accordance with the heuristic character of their research.

Despite the fact that Hébert, Scott, and Frye insist upon a notion of the literal that depends upon equivalences and norms that bear primarily upon the target-language, it might be remarked that "literal," nevertheless, seems to emphasize adequacy. Certain problems may arise, however, even when a translation appears literal, and this is because the role of language and culture in Canada is, as in most bilingual countries asymmetrical. What appears as equivalence may not adequately reflect the political relations between the two cultures in which the translation occurs. In Canada English carries a dominant role. As Sherry Simon remarks, commenting on a text by R.-Albert Benoit, "La 'servilité' dont il est question est double, à la fois d'ordre linguistique et politique. Cette double insertion de la traduction dans la vie québécoise est fondamentale et constitutive" (Simon, p. 52). Hence, it could be asserted that the observations I have made are primarily of use in the anglophone language-system. I have stressed the function of the geno-text within the target-language in the instance of Scott, however, because this is precisely what he shares with both anglophone and francophone translators.

5. Delisle notes in his "Chronologie, 1534-1984," as the first entry under 1534: "Jacques Cartier capture deux Iroquois de Stadaconé (Québec) [...] et les emmène en France où il leur fait apprendre les rudiments de la langue française" (Delisle, p. 51). As Todorov is at pains to argue in La Conquête de l'Amerique, the point of departure for translation practices is inevitably political. 
There is a further aspect of the problem of the literal in the translation of Hébert. As Kathy Mezei reminds us, arguing from another cultural perspective, the male translator of a woman's text may overlook crucial points, just as Scott did not seem to notice in his first rendering of "cette enfant" that the gender is female and simply translates it as "this child" (Mezei, p. 71). She also points out that other men, with one exception (a translator who read Dialogue), made the same error. For Barbara Godard, this is "the most celebrated case of [...] a sexist shift of meaning" in the history of Canadian literary translation of which she is aware (Godard 1984, p. 16). Her discussion elaborates upon Mezei's, and it is used as part of a larger discussion on the gender problems raised by Québécois poetry written by women. As she remarks, in the work of writers such as Nicole Brossard, gender difference is marked more graphically than normally in French, not to speak of English. For example, Brossard's book entitled L'Amer, a pun based on the words amer (bitter), mer (sea) and mere (mother), and possessing echoes of aimer, poses insoluble problems for the translator. Besides the pun, it is designed to portray the absence of the feminine in the absence of the (mute) " $\mathrm{e}$ " in mere. While Godard admits defeat in her own title (These Our Mothers), she took other steps in order to meet Brossard's challenge in the English text. As she indicates," $[t] 0$ give some idea of this word play to an English audience I have introduced plays on his-story/her-story more familiar to anglophone feminists, and created neologisms such as "s(h)ea" or re(her)ality (Godard 1984, p. 17). She was more successful, although she credits Ray Ellenwood, with the title Amantes, which she rendered as Lovhers.

As she admits, and not entirely ruefully, in the preface to Lovhers, "it is obvious that Lovhers is not Amantes," but "it effects its own work on language" (Godard, 1986, p. 11). Indeed, the English is to be considered a transformation and participates in the play of differences between the two texts. What is striking about both Godard's theory and her practice is her preoccupation with equivalence, for it is precisely here that translation theory and feminist theory converge, particularly in the understanding of the paradox as enunciated by Annie Brisset for whom translation is "une opération paradoxale, c'est-à-dire une opération dialectique et réflexive, capable de révéler certaines limites de la doxa critique" (Brisset 192). As Godard puts it, "it [rewriting, repetition, quotation, translation] is para-doxal, both like and 
unlike the doxa" (Godard, 1989, 49). Clearly, feminist discourse, which is often a discourse of subversion that practices paradox, is a refusal of equivalence, of the same (cf. Gallop, p. 64). Not only are the consequences of such thinking significant for the target-text, but also they make it clear that in the instance of Godard and Brossard there is an agreement, at least, on the level of ideology. This means that the notion of the target-text as a hypertext that transparently allows the dominance of the source-text to shine through the translation is denied. Like parody, however, the translated text foregrounds the intertextual relation of both hypertext and hypotext (Godard, 1989, p. 50; Brisset, pp. 192-93). A further consequence would be, to return to the schema above, that the feminist translator works often between geno-text 1 and 2 , the axis along which shared assumptions are ludically elaborated. Moreover, the line from pheno-text 1 and 2 is indirect, suggesting the concentration of the translator is held by all corners of the diagram at once and dialectically. "In this," Godard notes, "feminist discourse presents transformation as performance as a model for translation," and as she states earlier in the same paragraph, "[t]ranslation, in this theory of feminist disccurse, is production, not reproduction" (Godard, 1984, p. 47). The traditional notion of translation as an exercise in losing is, therefore, in many ways obviated. "Voilà pourquoi," to cite Brisset, "c'est dans la faille, ou le surplus, qui sépare le texte-source du textecible qu'on peut observer comment le sujet traduisant embraye ou assigne le sens" (Brisset, p. 207). The act of shifting and assigning, that hovers between loss and gain, occurs, I would argue, with respect to geno-text 2 and, as a result, underscores the value of its function in the act of translating.

In an unpublished journal entry dated 19 November 1989, the date of the earlier version of this paper, Godard made the following observation on the translation model that I proposed:

To discern textual meaning in translation, it is necessary to look at the generational level, Blodgett suggested. Phenotext 2 is always posed in relation to another text, to both phenotext 1 and genotext 2. What is important, however, is that there is engagement with two signifying systems: translation is more than mere craft. Political necessity intervenes at a mediating point where genotext 2 regulates the norms of textual 
production for a translation. The genotext is a guarantor of discursive norm functions to determine what is not acceptable with respect to these norms and, hence, what is nontranslatable. In this process, the encounter with the other is only apparent: it is the imbrication of the translated text in the polysystem of its own language that determines value and meaning.

Godard then goes on to remark upon her differences with the model, which I have endeavoured to accomodate. It is, she says, "suggestive [...] [b]ut not quite the one for this [Brossard's Picture Theory] translation. A third trajectory which more closely maps my process would move from phenotext 1 to genotext 1 , then to genotext 2 in order to produce phenotext 2 ." Such a formulation clearly suggests that the threshold for the target-text is, finally, geno-text 2 , and given the significance of the play between subject and other in Godard's notion of translation discourse, one might infer that geno-text 2 is in a certain sense privileged.

While their reasons would differ for occupying geno-text 2 , both Scott and Godard assure us of its significance. It has already been noted that translation from anglophone to francophone texts raises other questions, which problematize pheno-text 1 as a text of domination. Jacques Brault, who is one of Québec's more distinguished poets, has gone so far as to develop a notion of "nontraduction." Speaking for Québec, he notes that "nous n'aimons ni traduire ni être traduits," inasmuch as "[1]es clefs de la traduction appartiennent aux puissants"; for, while there may be no universal language, there are colonizing languages, "et nous l'éprouvons durement, chaque jour" (Brault, 1975, p. 16). The solution is an "inter-texte," "un texte, ni d'autre, ni de moi" (Brault, 1975, p. 50). ${ }^{6}$ This is a position that is asymmetrically,

6. Toury argues that "the language used in translation tends to be interlanguage" and that "a translation is [...] an 'inter-text' by definition" (1980, p. 75). He means by this a dialect appropriate to transfer shared by translators in a given literary system. Brault's point bears upon a text that can be, if only in a figurative but still significant sense, distinct from what is usually referred to as source and target. 
perhaps paradoxically, related to Godard's, ${ }^{7}$ proceeding from other preoccupations, that appears, in fact, to prevent domination by either source-text or the original geno-text. Brault would control the process centred primarily in his own geno-text, and, in a way more radical than Godard, he urges his fellow Québécois poets to "pratiquer sans vergogne les démarches d'appropriation, de vol à l'étalage, de trahison et de détournement de sens qu'implique la traduction de la poésie" (Brault 1977, 30). In this instance, one might infer that Brault avoids the movement toward geno-text 1, which both Scott and Godard make, except to find possibilities for transposition.

What I am proposing by means of the above model and suggestions for its use cannot claim to be more than an hypothese de travail. Its significance for the study of the Canadian literatures is that it indicates that despite ideological difference, there is a common understanding of where the act of translation proceeds from. Adequacy is not sought, but a certain encounter with the other is (cf. Jones, p. 80). The place of that encounter is only apparently in a text, whether source or target. It lies where meaning is engendered, which is another way of saying, as Scott does, that "[a] translation can thus never be said to be finally completed, even for one translator" (Hébert and Scott, p. 94), for it is prepared (and here, I suppose, it may be said to differ from the source) under the sign of non-closure. Such a position is shared by both Godard, who remarks in her journal, "[i]nitiating in this way the critical work of metafiction, translation is a figure that refuses closure" and Brault, who remarks of the "nontraduction" that "[e]lle reste en état d'alerte," only to be found "dans le passage, dans l'intertexte" (Brault, 1975, p. 95). The translation's existence and survival is designed to lead the reader inevitably to the continuous problem of how signifying takes place, ensuring, finally, in each new reading that even the sourcetext is not immobile, but part of the same process.

University of Alberta

7. While Godard has recently commented on translation as intertextuality, her use of the term is more conventional. It does not pose a third text, the text as sublation, as characteristic of the translated text (Godard, 1989, p. 48). 


\section{References}

BLODGETT, E.D. (1982). Configuration: Essays in the Canadian Literatures. Downsview, ECW Press.

BRAULT, Jacques (1975). Poèmes des quatre côtés. Chambly, Éditions du Norô̂t.

(1977). "Remarques sur la traduction de la poésie." Ellipse, 21, pp. 10-35.

BRISSET, Annie (1985). "La Traduction comme transformation para-doxale." Texte, IV, pp. 191-207.

DELISLE, Jean (1987). La Traduction au Canada/Translation in Canada 1534-1984. Ottawa, Les Presses de l'Université d'Ottawa.

EVEN-ZOHAR, Itamar (1990). "Polysystem Studies". Poetics Today, XI, 1.

(1978). "The Position of Translated Literature Within the Literary Polysytem." Literature and Translation: New Perspectives in Literary Studies. Eds. James S. Holmes, José Lambert and Raymond van den Broek. Leuven, ACCO.

GALLOP, Jane (1982). The Daughter's Seduction: Feminism and Psychoanalysis. Ithaca, Comell Univ. Press.

GODARD, Barbara (1984). "Language and Sexual Difference: The Case of Translation." Atkinson Review of Canadian Studies, II,1 (Fall-Winter), pp. 13-20.

(1986). Lovhers. Montréal, Guernica.

(1989). "Theorizing Feminist Discourse/Translation."

Tessera, VI (Spring/printemps), pp. 42-53. 
Journal. Unpublished.

HÉBERT, Anne and Frank Scott (1970). Dialogue sur la traduction: d propos du "Tombeau de rois". Montréal, HMH.

HERMANS, Theo., ed. (1984). The Manipulation of Literature: Studies in Literary Translation. New York, St. Martin's.

JAKOBSON, Roman (1959). "On Linguistic Aspects of Translation." On Translation. Ed. Reuben A. Brower. Cambridge, Harvard UP.

JONES, D.G. (1977). "Grounds for Translation." Ellipse, 21, pp. 58-91.

KELLY, Louis (1979). The True Interpreter. Oxford, Blackwell.

KRISTEVA, Julia (1974). La Révolution du langage poétique L'Avant-Garde a la fin du XIX' siecle: Lautréamont et Mallarmé. Paris, Seuil.

LEFEVERE, André (1982). "Literary Theory and Translated Literature." Dispositio, 7, pp. 3-22.

LEVY, Jiri (1969). Die literarische Übersetzung: Theorie einer Kunstgattung. Frankfurt am M, Athenäum.

MARCHAND, Pierre (1976). "À propos de la traduction du 'Tombeau des rois.'" Meta, XXI, 2 (juin), pp. 155-60.

MEZEI, Kathy (1984). "The Scales of Translation: The EnglishCanadian Poet as Literal Translator." 54, 2 (April-June), pp. 63-84.

MOISAN, Clément (1986). Comparaison et raison: Essais sur l'histoire et l'institution des littératures canadienne et québécoise. Lasalle, Hurtubise HMH. 
PAZ, Octavio (1976). "Interview." Modern Language Notes, 91, pp. 1073-98.

SIMON, Sherry (1989). L'Inscription sociale de la traduction au Québec. Québec, OLF/Gouvernement du Québec.

STEINER, George (1975). After Babel: Aspects of Language and Translation. Oxford, Oxford Univ. Press.

STRATFORD, Philip (1990). "Translation." Literary History of Canada: Vol 4. Ed. William H. New et al. Toronto, Buffalo, London, University of Toronto Press.

TODOROV, Tzvetan (1982). La Conquête de l'Amérique. Paris, Seuil.

TOURY, Gideon (1980). In Search of a Theory of Translation. Tel Aviv, The Porter Institute for Poetics and Semiotics.

(1982). "A Rationale for Translation Studies." Dispositio, 7, pp. 23-39. 